New York at Cortland, was appointed assistant professor of history at the University of Kentucky in September, 1964.

Sherman David Spector was promoted to associate professor of history and government at Sage College' in September, 1965.

Paul R. Sweet has been serving as American Consul General in Stuttgart, Germany, since November, 1963.

Glenn Torrey, of Kansas State Teachers College at Emporia, was promoted to professor of social sciences in September, 1965.

Solomon Wank was promoted to associate professor and made chairman of the history department at Franklin and Marshall College in the summer of 1965.

Stanley B. Winters was promoted to associate professor of history and appointed associate chairman of the department at Newark College of Engineering in September, 1965.

Joseph F. Zacek, formerly of Occidental College, was appointed assistant professor of history at the University of California at Los Angeles in July, 1965.

\title{
PRIZES, FELLOWSHIPS, SCHOLARSHIPS, AND RESEARCH GRANTS
}

Richard E. Allen, of Columbia University, did research in the fall of 1964 in Berne, Geneva, Paris, London, Amsterdam, The Hague, Vienna, Graz, Budapest, Debrecen, and Munich. He had a grant from the Inter-University Committee on Travel Grants to assist him in this work.

George Bárány, of the University of Denver, received summer research grants for 1964 from the American Council of Learned Societies and the Austrian Ministry of Education to continue his research on Count Stephen Széchenyi.

Thomas M. Barker, of the State University of New York at Albany, received a grant from the SUNY Research Foundation to complete his work on the Turkish siege of Vienna in 1683.

Frederick Dumin, of Washington State University, was 
awarded a grant-in-aid for the summer of 1965 from Washington State University to carry on further investigation at the Hoover Institute in Palo Alto, California, on the background of the Anschluss movement in 1918-19.

Myron Greene, a graduate student at Indiana University, received a one-year fellowship from the Inter-University Committee on Travel Grants to do research in Prague from February, 1965, until January, 1966, on his doctoral dissertation on Masaryk as an historian.

Nachum T. Gross, of the University of California at Berkeley, received a summer research fellowship in 1965 from the Harvard University Graduate School of Business Administration to work in the Baker and Widener libraries on his doctoral dissertation on industrialization in Austria during the nineteenth century.

Bascom Barry Hayes, of the University of California at Riverside, has been awarded an intramural research grant from the University of California to do research in Germany and Austria during the summer of 1966.

Roger Heacock, a graduate student at the University of Denver, has received an award from the Austrian Ministry of Education to do research in Vienna in 1965-66 on his doctoral dissertation concerning German-Austrian relations during World War I.

Keith Hitchins, of Rice University, is spending the academic year 1965-66 in Rumania on a grant from the Joint Committee of the American Council of Learned Societies and the Social Science Research Council and the Rumanian government.

Emile Karafiol, of the University of North Carolina, received a research grant from the Duke-North Carolina Cooperative Program in the Humanities for research in Austria during the summer of 1965 on Metternich's German policy, 1814-20.

Gerhard F. Kramer, a graduate student at the University of Missouri, was awarded a Fulbright scholarship in 1965-66 to work in Vienna on his dissertation on Catherine the Great's second war with Turkey, 1787-92.

Helen Liebel, of the University of Alberta at Edmonton, 
received a Social Science Research Council of Canada grant this past summer to do research on the economic theories of Joseph II.

William Lofgren, a graduate student at Indiana University, was awarded an Inter-University Committee on Travel Grants fellowship to spend the period from February, 1965, to August, 1966, in Prague doing research for his doctoral dissertation on Karel Kramár and Czech political development.

Myron J. Low, presently a visiting instructor at Rice University, received a University of Texas Exchange Fellowship and spent the academic year 1964-65 at the Free University in Berlin doing research on German-Austrian diplomacy before World War I.

Duane P. Myers, a graduate student at Yale University, was awarded a research grant from the Alexander von Humboldt Stiftung, Bad Godesberg, Germany, to do research on the German-Austrian Anschluss after World War I in 1964-65.

Gunther E. Rothenberg, of the University of New Mexico, received a summer grant for 1965 from the American Philosophical Society to begin research on the history of the Austrian Schutzbund.

Ivan L. Rudnytsky, of La Salle College, received a faculty research grant from La Salle College to do research in Vienna during the summer of 1965 . He also obtained a grant from the American Council of Learned Societies for research on the history of the Carpatho-Ukraine during the academic year 1965-66.

Paul W. Schroeder, of the University of Illinois, was awarded grants-in-aid from the American Council of Learned Societies and the American Philosophical Society, to do research in Vienna during the summer of 1965 on Austrian foreign policy under Metternich (1823-30) and Buol (1853-56).

Gerard E. Silberstein, of the University of Kentucky, received a research grant from the University of Kentucky this past summer to work at the Widener Library on the diplomacy of the Central Powers from 1914 to 1917.

Solomon Wank, of Franklin and Marshall College, was awarded a grant from the American Philosophical Society (Penrose Fund) in the spring of 1965 to microfilm material 
in the Czechoslovak archives relative to Count Alois Lexa von Aehrenthal.

Joseph F. Zacek, of the University of California at Los Angeles, received a grant from the Joint Committee on Slavic Studies of the American Council of Learned Societies and the Social Science Research Committee for research in Czechoslovakia during the summer of 1965 on a biography of František Palacký.

\section{RESEARCH ACTIVITIES AND LECTURES}

Stephen Borsody, of Chatham College, gave a lecture on "Hungary in the Bloc: Integration-Disintegration" at a symposium on "New Dimensions in East-West Relations" at Columbia University on July 30, 1965, which was sponsored jointly by the Kossuth Foundation of New York and the Columbia University Institute on East Central Europe.

Stephen Fischer-Galati, of Wayne State University, read a paper on "Peasantism in Interwar Eastern Europe" at the Stanford Conference on Eastern Europe in October, 1964.

Mimi Grossberg delivered a lecture on "Joseph Roth, his Fate and his Work" at the Austrian Institute in 1964.

Charles W. Hallberg, of Queens College, spent the academic year 1964-65 in Vienna doing research.

Ivo J. Lederer, of Stanford University, lectured on "Nationalism in Eastern Europe" to the NDEA Institute for Teachers of History at the University of Denver in July, 1965.

G. C. Paikert, of LeMoyne College, spent the academic year 1964-65 on sabbatical leave in Europe doing research on the problems of Hungary's ethnic minorities, 1867-1918.

\section{PUBLICATIONS}

In 1964 Hermann Böhlaus Nachf., Graz, published a two volume German edition of Robert A. Kann's The Multinational Empire: Nationalism and National Reform in the Habsburg Monarchy 1848-1918 (2 vols., New York: Columbia University Press, 1950) under the title Das Nationalitätenproblem der Habsburgermonarchie. Several new chapters were added in the German edition. Others were enlarged, and the bibliographies and notes were brought up to date. 